\title{
Engagement Desa Kebontunggul : Menuju Desa Brilian Berkonsep Digitalisasi Badan Usaha Milik Desa (E-Bumdes)
}

\author{
Pipit Sari Puspitorini $^{1)}$, Rachman Sidharta Arisandi' ${ }^{2}$, Siandi $^{3)}$ \\ Universitas Islam Majapahit ${ }^{1,2)}$, Desa Kebontunggul ${ }^{3)}$ \\ Email : puspitorini_ie@unim.ac.id
}

\begin{abstract}
The basic issues of a BRILian village promoted by the Indonesian public bank 2020 and Kebontunggul village as the competition's first batch entry, has inspired the writer to accompany BUMDes because the village has a potential of natural resources. The goal is to optimize the management of the BUMDes Gajah Mada units toward a BRILian village with the digitalization concept. The method used is a strategic management approach consisting of (1) Need assessment, conducting observations and interviews with BUMDes managers, (2) Strategic planning, consisting of (a) Intensive (horizontal integration and concentric diversification) and (b) diversification (penetration and market development), (3) Digitalization technology serves to expand the marketing of the Mbencireng valley tourist area, (4) Become an Independent BUMDes and achieve BRILian Village. The results in developing strategic management are (1) collaborating to develop ownership management with third parties, (2) applying the concept of eco farming tourism with homestay and cycling facilities and (3) developing BUMDes web with digitalization on market penetration and development strategies. This assistance will have significant implications for the partners.
\end{abstract}

Keywords: BUMDes, BRILian Village, Digitalization, Engagement and Kebontunggult

\begin{abstract}
Abstrak
Isu pokok tentang Desa BRILian yang dicanangkan oleh Bank Rakyat Indonesia tahun 2020 dan Desa Kebontunggul sebagai peserta Batch pertama dalam kompetisi tersebut, telah menginspirasi penulis untuk mendampingi BUMDes karena desa tersebut mempunyai potensi sumber daya alam. Tujuannya adalah mengoptimalkan pengelolaan unit BUMDes Gajah Mada menuju Desa BRILian dengan konsep digitalisasi. Metode yang digunakan menggunakan pendekatan manajemen strategi yang terdiri dari (1). Need assessment, melakukan observasi dan wawancara dengan pihak pengelola BUMDes, (2). Perencanaan strategi, terdiri strategi (a). Intensif (integrasi horizontal dan diversifikasi konsentrik dan (b). diversifikasi (penetrasi dan pengembangan pasar), (3). Teknologi digitalisasi berfungsi untuk memperluas pemasaran area wisata Lembah Mbencireng, (4). Menjadi BUMDes Mandiri dan meraih Desa BRILian. Hasil dalam mengembangkan manajemen strategi yaitu berkolaborasi mengembangkan manajemen kepemilikan dengan pihak ketiga,
\end{abstract}


menerapkan konsep wisata eco farming dengan fasilitas homestay dan bersepeda serta mengembangkan web BUMDes dengan digitalisasi pada strategi penetrasi dan pengembangan pasar. Pendampingan ini akan mempunyai implikasi secara signifikan terhadap mitra kedepan.

Kata Kunci : BUMDes, Desa BRILian, Digitalisasi, Engagement, dan Kebontunggul

\section{PENDAHULUAN}

Desa Kebontunggul merupakan desa berprestasi nasional yang berbenah menuju desa BRILian di bawah kepemimpinan bapak Siandi, SH., MM, pada tahun 2013 mendapatkan penghargaan dari kementerian dalam negeri sebagai penerima PAKARTI utama I tingkat nasional pemanfaatan terbaik hasil toga kategori kabupaten. Bapak kepala desa mempunyai masterplan pengembangan Desa Kebontunggul menjadi desa mandiri dan BRILian yang diimplementasikan melalui Badan Usaha Milik Desa yang diberi nama sebagai BUMDes Gajah Mada, Kebontunggul, Gondang Mojokerto di bawah lereng Gunung Welirang dengan empat dusun yang mengelilinginya, yaitu Penunggulan, Sengon, Jemanik dan Kudur dengan jumlah penduduk dan Kartu Keluarga (KK) adalah 1692 orang dan 600 dengan luas wilayah 263,215 di tahun 2019. Jarak tempuh Desa Kebontunggul ke ibu kota Kecamatan Gondang yaitu sekitar satu kilometer. Sedangkan jarak ke ibu kota Kabupaten Mojokerto adalah sekitar dua puluh lima kilometer.

Desa BRILian merupakan sebuah program yang dicanangkan Bank Rakyat Indonesia guna memacu continuous innovation bagi desa sekaligus unit-unit penghasil yang kita kenal sebagai Badan Usaha Milik Desa (BUMDes). Tujuan desa BRILian yang merupakan inisiasi Program BRI Tahun 2020, menciptakan inovasi berkelanjutan untuk menggali potensi desanya menjadikan masyarakat lebih berdaya yaitu, (1) pengelolaan desa yang lebih menginspirasi, 2). menjadi desa yang inovatif dan memotivasi yang lainnya, (3) menjadi influencer BRI, (4). membantu memperkuat hubungan BRI dengan masyarakat. Kriteria yang digunakan adalah (1) keaktifan delegasi, (2) kelengkapan adminstrasi dan kelembagaan, (3) penerapan digitalisasi desa, (4) kreativitas dalam decision making, (5) meningkatkan potensi desa untuk kesejahteraan warga desa (Co, 2021). Selain itu, tujuan utama dari program pengabdian ini adalah mendorong perekonomian desa melalui pendampingan digitalisasi BUMDes dalam meningkatkan perekonomian masyarakat melalui pengembangan UMKM (Hapsari, 2019).

Dalam upayanya menuju desa BRILian, Desa Kebontunggul dan BUMDes Gajah Mada telah menjadi peserta BRI incubator goes go desa BRILian pada tahun 2021. BUMDes Gajah Mada memiliki tujuh usaha pengelolaan, visinya adalah menjadi badan usaha milik desa yang profesional dan mandiri tahun 2020. Sesuai dengan Permendes nomor 4 tahun 2015 tentang pendirian, pengurusan, dan pengelolaan, dan pembubaran badan usaha milik desa. BUMDes dapat berbentuk perseroan ataupun lembaga keuangan mikro yang bertujuan untuk kesejahteraan desa. Sedangkan tujuannya adalah (1) meningkatkan dan mengoptimalkan perekonomian dan kesejahteraan desa, (2) menciptakan peluang dan jaringan untuk mensejahterakan masyarakat desa serta (3) menciptakan lapangan kerja, (4) meningkatkan pendapatan. Dengan adanya PerMen, kedudukan BUMDes sangatlah berpengaruh terhadap keberlangsungan desa tersebut. Menurut data kemendesa bahwa jumlah BUMDes di Indonesia terus mengalami rata-rata peningkatan unit dan persentase sebesar 23.222 unit dan 4.1\%. (Hapsari, 2019). Dan perkembangan BUMDes di Indonesia diilustrasikan pada Gambar 1. 


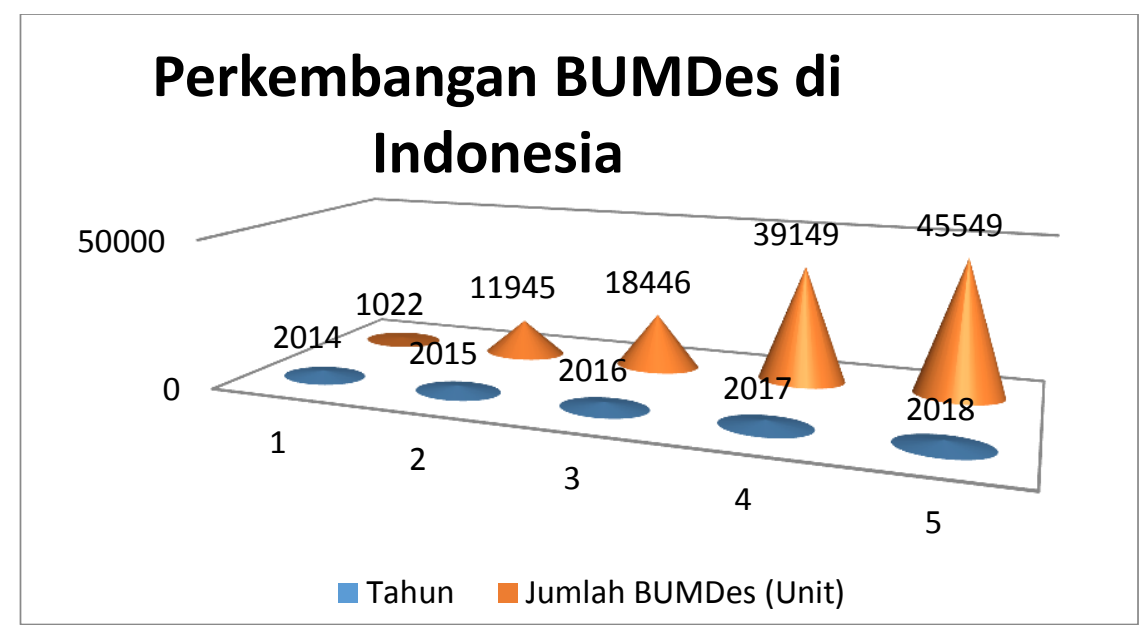

(Sumber : Kemendesa, 2019)

Gambar 1. Perkembangan BUMDes di Indonesia tahun 2014-2018

Hasil wawancara pelaksana pengabdian dengan ketua BUMDes, (Hartini, 2021) bahwa pendirian awal BUMDes kurang dari Rp. 100.000.000 dan sampai saat ini melebihi berkali-kali lipat. BUMDes Gajah Mada yang terletak di Jalan Welirang No. 36 Kebontunggul Gondang Mojokerto mempunyai 7 (tujuh) area pengelolaan, diantaranya adalah wisata Lembah Mbencireng, Sistem Penyediaan Air Minum (SPAM), gapoktan, lahan pertanian, simpan pinjam, pengelolaan PPOB (Payment Point Online Bank) Puskut BTN dan Brilink serta bank sampah dan saat ini berkembang menjadi PERTASHOP. Secara umum, permasalahan yang dihadapi oleh BUMDes adalah (1) persepsi yang salah dari masyarakat tentang dana bantuan pemerintah, (2) banyaknya praktek rentenir yang terjadi di masyarakat dan (3) sulit mencari orang yang bersedia bekerja untuk desa. Selain itu permasalahan yang spesifik adalah (1) belum optimalnya pengelolaan unit BUMDes, (2) hanya satu unit yang produktif, banyak UKM binaan, BUMDes mengalami penurunan order terutama pada jamu empon-empon. Pada program ini, difokuskan pada bidang manajerial dengan permasalahan mitra yaitu belum optimalnya pengelolaan unit BUMDes dan peningkatan keterampilan sumber daya masyarakat. Sedangkan tujuan kegiatan ini mengoptimalkan pengelolaan unit BUMDes Gajah Mada menuju desa BRILian dengan konsep digitalisasi. Sedangkan output (Puspitorini, 2019), bahwa pemberdayaan memberikan transfer knowledge yang mempunyai value added secara significant pada perubahan mindset mitra terkait transfer knowledge.

\section{Badan Usaha Milik Desa}

Maryunani (2008) menyatakan bahwa ada tujuh variabel yang membedakan BUMDes dengan lembaga lainnya, (1) kebersamaam dalam mengelola kepemilikan, 2) modal usaha sebesar $51 \%$ dan $49 \%$ dari masyarakat dan pemerintah desa, (3) pedoman bisnis mengacu lokal wisdom, (4) bidang yang dikelola berdasarkan hasil survei pasar, (5) laba dituangkan dalam kebijakan desa (village policy) untuk meningkatkan kesejahteraan anggota, (6) Integrasi fasilitas berasal dari Pemerintah, (7) monitoring bersama stakeholder, sedangkan menurut (Seyadi, 2003), bahwa peran BUMDes untuk (1) meningkatkan perekonomian masyarakat desa khususnya (ekonomi dan sosial), (2) menaikkan kualitas kehidupan masyarakat, (3) memperkuat BUMDes sebagai dasar ketahanan perekonomian nasional, (4) memfasilitasi dan meningkatkan kemakmuran masyarakat dengan tolok ukur penghasilan dan pendapatan

Peranan BUMDes saat ini semakin besar dalam meningkatkan perekonomian masyarakat, adanya faktor penghambat yaitu adanya problematika internal terkait sumber 
daya dalam pengembangan sistem tata kelola BUMDes (Firdaus, 2020). Sedangkan menurut (Sasauw, 2018) bahwa variabel inovasi dalam pengembangan BUMDes masih kurang tetapi variabel yang lain seperti keuletan dan ketelitian cukup berdampak pada kinerja dan ketercapian target yaitu mensejahterahkan masyarakat. Berbeda dengan (Rahmawati, 2020) bahwa masih banyak BUMDes yang belum signifikan mendukung perekonomian desa sehinga diperlukan fokus untuk meningkatkan kinerja yaitu perbaikan sarana dan prasarana, inovasi dalam menghasilkan produk, mengembangkan jaringan distribusi, diperlukan pelatihan SDM serta memiliki budaya organisasi.

\section{METODE}

Metode pelaksanaan yang dilakukan menggunakan pendekatan manajemen strategi difokuskan pada pengembangan BUMDes dengan konsep digitalisasi dalam proses pengelolaannya. Lokasi kegiatan di Lembah Mbencireng Desa Kebontunggul Kecamatan Gondang dengan jarak 19.3 Km atau sekitar 30 menit dari Universitas Islam Majapahit. Pada lokasi tersebut diilustrasikan pada Gambar 2.

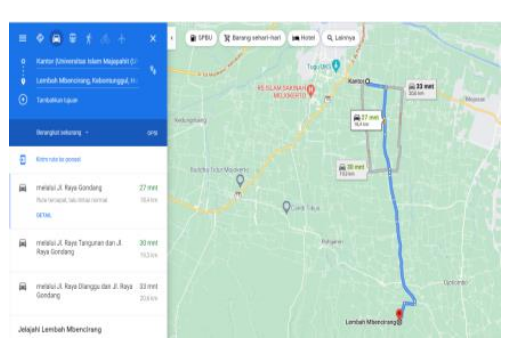

(Sumber : Diambil dari google map, 2021) (a). Google map lokasi BUMDes

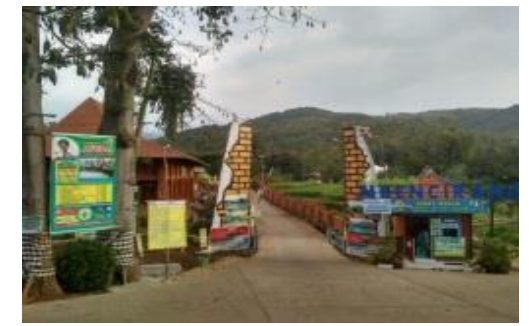

(Sumber : Diambil ketika wawancara, 2021)

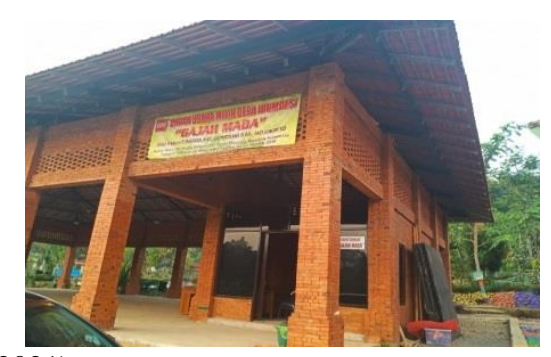

(b). Kantor BUMDes Gajah Mada

Gambar 2. Lokasi pendampingan UNIM dengan Desa Kebontunggul sebagai Mitra

BUMDes berkembang dan mandiri secara perekonomian akan dapat tercapai jika terjadinya engagement yang kuat antara akademisi, BUMDes, masyarakat, UMKM binaan dan stakeholder lain yang sangat mendukung seperti pemerintahan, industri dan lainnya.

Penyelesaian permasalahan denagn menggunakan pendekatan manajemen strategi yang diperlukan difokuskan pada :

(1). Need assessment

Pada strategi pertama diperlukan wawancara dan observasi ke lapangan untuk mendapatkan data sesuai. Wawancara dilakukan dengan bapak kepala desa dan Ibu Hartini selaku ketua BUMDes Desa Kebontunggul

(2). Perencanaan strategi

Metode yang kedua terdiri (a) Intensif yang terdiri dari (i) integrasi horizontal dan (ii) diversifikasi konsentrik dan (b) diversifikasi, yaitu (i) penetrasi dan (ii) pengembangan pasar.

(3). Teknologi digitalisasi

Teknologi yang diadopsi menggunakan internet of thing dan artificial intelegent (kecerdasan buatan) yang berfungsi untuk memperluas pemasaran hasil BUMDes terutama wisata Lembah Mbencireng

(4). BUMDes mandiri

Kegiatan ini berupa pendampingan BUMDes untuk mengoptimalkan pengelolaan unit BUMDes dalam meningkatkan perekonomian masyarakat terutama pengembangan skill sumber daya manuasianya 
(5). Meraih desa BRILian

Pendampingan dengan memperhatikan empat kriteria yang ditetapkan oleh BRI sebagai official desa BRILian.

Metode yang dilakukan dalam pengembangan BUMDes Gajah Mada menuju desa BRILian diilustrasikan pada Gambar 3.

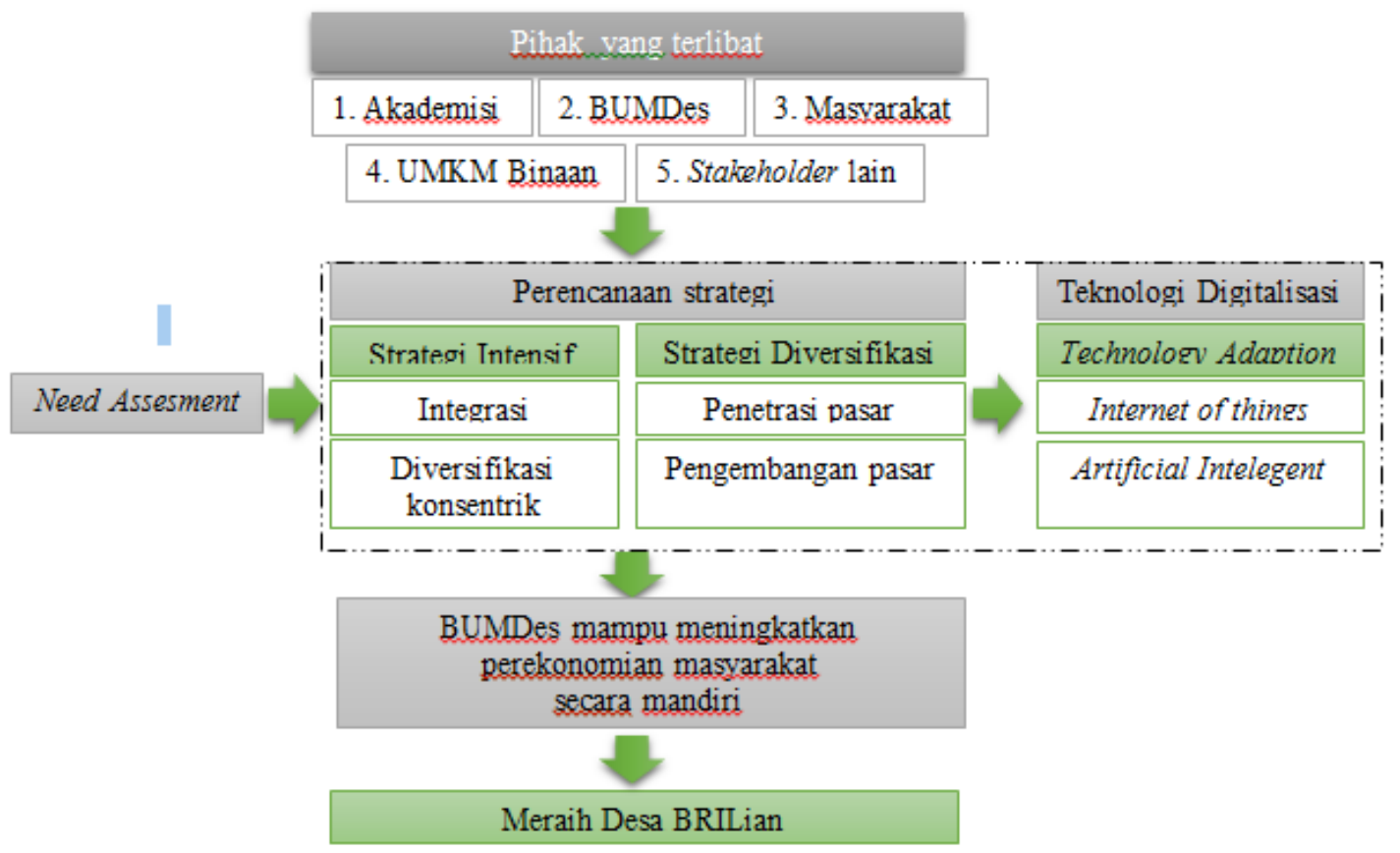

Gambar 3. Konsep pengembangan BUMDes Gajah Mada menuju desa BRILian

\section{HASIL DAN PEMBAHASAN}

\section{Hasil}

Tahun 2020, BUMDes Gajah Mada mempunyai pengembangan di tujuh area, di tahun 2021 telah mengembangkan satu area yaitu PERTASHOP. Menurut (Siandi, 2021), pengembangan PERTASHOP mengintegrasikan yaitu pertama, sharing lahan tanah kas desa melalui peraturan desa, bekerjasama dengan Pemdes dan Pertamina (terdiri dari mesin, perijinan, order dan karyawan) dan akan dialihkan ke BUMDes jika telah siap mengoperasionalkan semuanya. Kedua, bekerjasama dengan BUMDes dengan sistem CODO ketiga, sharing hasil usaha bersama.

Pengembangan BUMDes untuk meraih desa BRILian, dilakukan pendampingan untuk memenuhi empat kriteria yaitu (Ibrahim, 2021)

(i) BUMDEs sebagai penggerak ekonomi desa

(ii). Digitalisasi yang terintegrasi BRI Link

(iii). Inovasi dalam memecahkan masalah (sosial desa dan kemasyarakatan)

(iv). Sustainability, dalam meningkatkan kesejahteraan masyarakat terutama anggota masyarakat.

Pengembangan BUMDes Gajah Mada menitikberatkan pada digitalisasi. Hal ini dikarenakan mengacu pada Indonesia dalam era digital dan membuka kunci digital BUMDes dan untuk menang di era digital, berdasarkan tabel 1 bahwa jumlah populasi dan pengguna perangkat digital sangat tinggi di Indonesia dan hal ini membuka peluang yang besar untuk 
market share BUMDes Gajah Mada terutama dalam pengeloalaan wisata khususnya Lembah Mbencireng. Perbandingan pengguna dan populasi diilustrasikan pada tabel 1.

Tabel 1. Perbandingan populasi dan pengguna perangkat digital di Indonesia

\begin{tabular}{|l|c|}
\hline \multicolumn{1}{|c|}{ Variabel } & Jumlah (juta) \\
\hline Jumlah populasi & 274,9 \\
\hline Pengguna internet & 202,6 \\
\hline Pengguna smartphone & 191,6 \\
\hline Pengguna sosial media & 170 \\
\hline Koneksi internet & 345,3 \\
\hline
\end{tabular}

(Sumber : (Kemp, 2021)

Lembah Mbencireng adalah brand dari wisata unggulan Desa Kebontunggul dimana arung jeram dan pembukaan pusat makanan (food center). Arung Jeram Landaian (AJL) merupakan wahana baru obyek wisata yang memacu adrenalin bagi anak muda sepanjang satu kilometer yang menyusuri sungai landaian di kaki Gunung Penanggungan dengan melewati dua desa yaitu Gumeng dan Kebontunggul. Penggunaan rute aliran sungai landaian karena airnya yang jernih, menyegarkan dan mempunyai debit air yang stabil meskipun dimusim kemarau. Titik awal berada di jembatan blogong Desa Gumeng menggunakan kendaraan shuttle dari Lembah Mbencireng. Ketika melakukan perjalanan terdapat rest area di pertengahan area Goa Landak sebelum mencapai titik tujuan. Disetiap perjalanan, di samping udara dan air yang berlimpah, bersih nan segar, juga terhampar pemandangan keindahan alam (natural view) pegunungan begitu menarik untuk dijadikan sarana relaksasi, penyegaran, dan rekreasi setelah melalui berbagai kepenatan dalam beraktifitas.

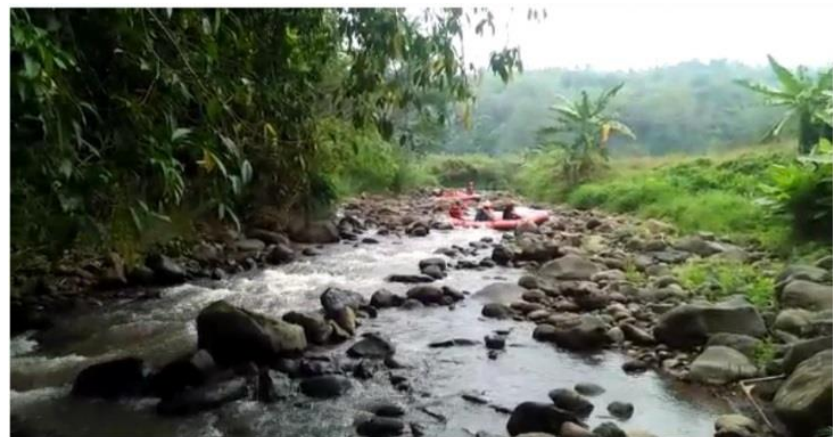

(Sumber : Foto koleksi BUMDes, 2021)

(a). Kegiatan arung jeram di Lembah Mbencireng

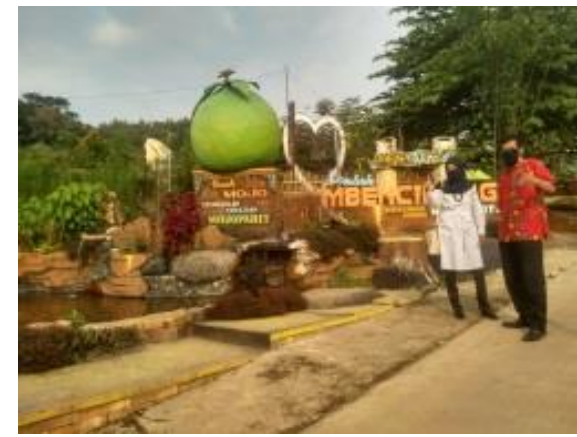

(b). Pelaksana dan Kepala desa

Gambar 4. Pelaksana dan kepala desa dan kegiatan arung jeram di Lembah Mbencireng

\section{Pembahasan}

Penerapan strategi untuk pengembangan BUMDes khususnya wisata adalah :

1. Integrasi horisontal

Bekerjasama dengan pihak ketiga untuk berkolaborasi dalam mengembangkan manajemen kepemilikan 
2. Diversifikasi konsentrik

Mendirikan homestay dengan konsep wisata eco farming di pedesaan dengan bersepeda

3. Penetrasi dan pengembangan pasar

Integrasi dengan digitalisasi dengan mengembangkan website BUMDes Gajah Mada

Tabel 2. Strategi dan definisi yang diterapkan

\begin{tabular}{|l|l|l|}
\hline \multicolumn{2}{|c|}{ Strategi } & \multicolumn{1}{c|}{ Definisi } \\
\hline Integrasi & Integrasi Horizontal & Meningkatkan kontrol atas pesaing \\
\hline Diversifikasi & Konsentrik & Diversifikasi produk/jasa yang masih berkaitan. \\
\hline Intensif & Penetrasi Pasar & $\begin{array}{l}\text { Menggunkaan strategi pemasaran dalam meningkat } \\
\text { kan pangsa pasar }\end{array}$ \\
\cline { 2 - 3 } & Pengembangan Pasar & $\begin{array}{l}\text { Memperluas geografis baru untuk memperkenal } \\
\text { kan produk/jasa. }\end{array}$ \\
\hline
\end{tabular}

(Sumber : (David, 2015)

\section{KESIMPULAN}

Output kegiatan ini adalah adanya transfer knowledge dan kesiapan pengelola dalam mengoptimalkan BUMDes Gajah Mada menuju desa BRILian dengan konsep digitalisasi. Brand sebagai desa BRILlian akan berdampak signifikan terhadap image Desa Kebontunggul yang akan mendatangkan pihak ketiga dalam berinvestasi sehingga berkorelasi positif terhadap kemandirian desa dalam melaksanakan Peraturan Pemerintah nomor 11 tahun 2021 pasal 3e tentang BUMDes, yaitu mengembangkan digital economy ecosystem di desa. (Indonesia, 2021)

\section{DAFTAR PUSTAKA}

Co, T. (2021). BRI Umumkan 10 Pemenang Desa BRILian Tahap 12021. https://bisnis.tempo.co/read/1451149/bri-umumkan-10-pemenang-desa-brilian-tahap$1-2021 /$ full\&view $=$ ok

David, F. R. (2015). Strategic Management: Concepts \& Cases. Salemba Empat Jakarta.

Firdaus, R. (2020). Peran Badan Usaha Milik Desa (BUMDES) Dalam Pemberdayaan Ekonomi Masyarakat Desa Manding Laok Kec.Manding Kab.Sumenep. Jurnal Inovasi Penelitian, 1(7), 1387-1394. https://stp-mataram.ejournal.id/JIP/article/view/235

Hapsari, P. H. (2019). BUMDes Menggerakan Ekonomi Desa. https://indonesiabaik.id/infografis/bumdes-menggerakan-ekonomi-desa

Hartini. (2021). Area BUMDes Gajah Mada dan pengelolaannya.

Ibrahim, S. (2021). Kriteria Penilaian Program Desa BRILian BRI Tahun 2021. https://makassar.tribunnews.com/2021/02/27/ini-kriteria-penilaian-program-desabrilian-bri-tahun-2021 ?page $=2$

Indonesia, P. R. (2021). Peraturan Pemerintah 11 Tahun 2021 Tentang Badan Usaha Milik Desa. Peraturan Pemerintah 11 Tahun 2021 Tentang Badan Usaha Milik Desa, 0865, $1-71$.

Kemp, S. (2021). Digital 2021: Indonesia. https://datareportal.com/reports/digital-2021indonesia

Maryunani. (2008). Pembangunan Bumdes dan Pemberdayaan Pemerintah Desa. Bandung: CV. Pustaka Setia.

Puspitorini, P. S. (2019). Rawan Bencana Berbasis Teknologi Informasi Pipit Sari Puspitorini, 2 Andhika Cahyono Putra.

Rahmawati, E. (2020). Analisis Pengelolaan Badan Usaha Milik Desa (Bum Desa) Di 
Kabupaten Bandung Barat. Jurnal Ilmiah Ekonomi Bisnis, 25(1), 1-13. https://doi.org/10.35760/eb.2020.v25i1.2386

Sasauw Chindy, G. R. dan W. W. (2018). Efektivitas Badan Usaha Milik Desa (Bumdes) Dalam Meningkatkan Masyarakat Di Desa Lenganeng Kecamatan Tabukan Utara Kabupaten Kepulauan Sangihe. Jurnal Eksekutif, 1(1), 1-10.

Seyadi. (2003). Bumdes Sebagai Alternatif Lembaga Keuangan Desa,. Yogyakarta: UPP STM YKPN.

Siandi. (2021). HAsil wawancara: Perkembangan BUMDes Gajah Mada pada area Wisata dan MOU dengan PERTAMINA. 